\title{
DIAGNOSTIKA BIOKOROZÍVNYCH NAPADNUTÍ PRVKOV STAVEBNÝCH KONŠTRUKCIÍ
}

\author{
DIAGNOSTICS OF BIOCORROSIVE ATTACK OF BUILDING STRUCTURES \\ ELEMENTS
}

RNDr. Terpáková Eva, Ph.D.

\begin{abstract}
ABSTRAKT
Výskyt porúch v stavebníctve, či už staršich alebo novších budov, môže mat' viacero príčin, môže to byt' spôsobené zlým návrhom, nesprávnou realizáciou, kvalitou použitého materiálu a tiež zanedbanou údržbou. Zvláštne problémy sú spojené s výskytom kolóniami baktérii, húb, plesní a iných mikroorganizmov, žijúcich na povrchu niektorých konštrukčných prvkov a častí objektov. Práca je zameraná na diagnostiku degradačných procesov, ktoré sa pozorovali na vybranom rodinnom dome. Biologické znehodnotenie stavebných materiálov a častí stavby je $\mathrm{v}$ dnešnej dobe vel'mi aktuálny problém, pretože degradácia prírodných a syntetických stavebných materiálov je úplne prirodzený a nezvratný proces, v ktorom sa významne podiel'ajú nielen abiotické korozívne látky, ale aj vyššie uvedené faktory. Výber diagnostických postupov a metodík na posúdenia degradácie preto zohráva dôôležitú úlohu aj z hl'adiska návrhu rekonštrukcie, trvanlivosti a tiež životnosti stavby.
\end{abstract}

Klúčové slová: biokorózia, diagnostika stavebných konštrukcií, sanácia

\section{ABSTRACT}

The occurrence of failures in construction of buildings, either older or newer, can have several causes, it can be a low quality design, realization, used material, and also neglect the maintenance of already existing building. Special problems are connected with presence societies of bacteria, fungi, moulds and other live organisms on the surface some construction parts and elements. The work is focused on a diagnostics of the degradation processes of selected family house. The bio-deterioration of building materials and parts of construction is nowadays very actual problem because degradation of natural and synthetic building materials is a natural and irreversible process in which significantly participate not only abiotical corrosive agents, but above mentioned factors. Therefore choice of diagnostic procedures and methodologies for assessing degradation plays an important role in terms of reconstruction design, durability and service life of construction too.

Key words: biocorrosion, diagnostics in civil construction, reconstruction

\section{1 ÚVOD}

Pri všeobecnom riešení diagnostiky stavebných konštrukcií je potrebné starostlivo zvážit' situáciu, vždy s prihliadnutím aj na skutočnost', či ide o novostavbu alebo či je objekt dlhoročne využívaný. Ďalším aspektom je prístup resp. starostlivost' o daný objekt zo strany vlastníka a užívatel'a stavby, pričom samozrejme nemusí íst' o ten istý subjekt, nakol'ko stavba alebo jej časti môžu byt' len v prenájme, čo čiastočne môže komplikovat' spôsob údržby. V mnohých prípadoch sa riešia poruchy až v období, kedy došlo ku výrazným zmenám technických parametrov, v krajnom prípade spojených až so statickými poruchami, čo si bude vyžadovat' už 
radikálny zásah do objektu. V posledných rokoch sa do popredia diagnostických posúdení dostáva okruh problémov, ktoré súvisia s biokorozívnym napadnutím. Z estetických dôvodov sú vo väčšom meradle riešené poškodenia v exteriéri stavieb (v zmysle myšlienky, že sú viac na očiach verejnosti). Častokrát sú však problémy týkajúce sa biokorózie závažnejšieho charakteru na prvkoch, ktoré sú v interiéri stavieb, nakol'ko tieto sú spojené s väčším rizikom zdravotného ohrozenia užívatel'ov. Je to pochopitel'né, nakol'ko v čase, kedy sa pristupuje ku radikálnejšiemu spôsobu odstránenia danej poruchy je už poškodenie $\mathrm{v}$ značnom rozsahu a to aj s teoretickým prestupom biodegradácie do vnútorných vrstiev poškodených prvkov, čo je možné identifikovat’ aj priamym - vizuálnym spôsobom.

Celkove je možné konštatovat', že napriek uvedeným faktom sú značné rezervy v oblasti riešenia biokorózie najmä obvodových plášt'ov panelových domov, ktoré sú ešte v pôvodnom stave, prípadne už aj po dodatočnej aplikácii kontaktného zatepl'ovacieho systému ETICS. Podobné situácie sa vyskytujú aj individuálne v prípade rodinných domov, ktoré už boli opatrené určitým systémom ETICS (Terpáková, 2016). Pri diagnostike stavu sa zvyčajne postupuje od získania všeobecných poznatkov a informácií až po podrobný prieskum, ktorý zahŕňa aj detailné analytické procedúry, či už chemické alebo mikrobiologické skúšanie. V príspevku budú diskutované praktické poznatky, získané z diagnostiky posúdenia biokorozívneho napadnutia časti fasády rodinného domu po 5 rokoch od realizácie zateplenia $\mathrm{v}$ konfrontácii s posúdením biokorozívnych zmien povrchových častí muriva v pivničných priestoroch daného rodinného domu.

\subsection{Popis objektu - fasáda}

Predmetom posúdenia bol objekt rodinného domu, ktorý sa nachádza cca $200 \mathrm{~m}$ od menej frekventovanej cesty 2. triedy v okrese Gelnica (Košický kraj). Budova sa nachádza na miernom svahovitom teréne, je čiastočne podpivničená, zo severnej strany sa nachádzajú v blízkosti okrasné dreviny a približne $10 \mathrm{~m}$ od pozemku tečie potôčik. Západná čast' domu je síce situovaná cca $5 \mathrm{~m}$ od paralelne situovanej budovy susedného rodinného domu, avšak tento je vzhl'adom na terénne podmienky umiestnený s určitým výškovým rozdielom tak, že v popoludňajších hodinách nedochádza $\mathrm{k}$ tieneniu posudzovanej časti RD, ale západná fasáda je relatívne intenzívne prehrievaná. V blízkosti južnej a východnej časti budovy sú ovocné stromy, kríky drobného ovocia a okrasné dreviny. Vek stavby je cca 60 rokov, v r. 2012 sa vykonala rekonštrukcia fasády RD s čiastočným zateplením. Fasáda je zateplená kontaktným zateplovacím systémom Extherm z tepelno-izolačnej dosky z expandovaného polystyrénu EPSF hrúbky $100 \mathrm{~mm}$. Izolant je lepený na pôvodnú fasádu, prídavné kotvenie je zabezpečené tanierovými hmoždinkami s plastovým tŕňom. Povrchová úprava fasády je akrylátová zatieraná (hladená) omietka Extherm, z farebným odtieňom svetlotehlovej farby a hrúbkou zrna do 1,5 $\mathrm{mm}$. Z hl'adiska realizácie rekonštrukcie stavby sa výrazne poruchy na fasáde v súčasnosti nepozorujú, avšak v podstate problematickou sa v poslednom období začína javit' severná čast' fasády. Realizácia vonkajšieho zateplenia bola zrealizovaná v súlade s STN 73 0540-2:2012. Napriek uvedenému faktu sa začali na povrchu fasády vizuálne pozorovat' zmeny, ktoré naznačujú biokorozívne procesy. Konkrétne sa na povrchu fasády približne do výšky 1,0-1,3m od úrovne terénu začali objavovat' nesúvislé vrstvičky sivo-zeleného povlaku, ktoré vyvolali potrebu detailného prieskumu. Vzhl'ad napadnutia fasády je dokumentovaný na obr.1.

Na napadnutých fasádach sa okrem farebných prejavov sa vo všeobecnosti pri biokorozívnych dejoch pozorujú aj d’alšie symptómy ako je tvorba trhliniek, prasklín, prípadne aj zmeny plošného charakteru - napr. odlupovanie povrchových vrstvičiek náterovej časti alebo aj omietky. Vizuálne pozorovaná prítomnost' kolónií rias, plesní a siníc už predstavuje vyšší stupeň deštrukcie. Vo všeobecnosti všetky anomálie znamenajú potrebu diagnostického posúdenia a následne návrh a realizáciu protiopatrení, ked’že každá negatívna zmena teoreticky ovplyvňuje životnost' a trvanlivost' stavby (Wasserbauer, 2000). V prípade posudzovaného objektu našt'astie neboli pozorované výraznejšie deštrukcie. 


\subsection{Poruchy podpivničenej časti objektu}

Ďalším problémom v posudzovanom objekte, ktorý je však dlhodobejšieho charakteru, je zavlhávanie podpivničenej časti rodinného domu a to najmä z východnej a južnej strany, čo korešponduje so situovaním stavby $\mathrm{v}$ teréne. Na stenách pivničných priestorov boli už v minulosti pozorované výskyty plesní, ktoré boli opakovane odstraňované dostupnými dezinfekčnými prostriedkami stavebnej chémie. Detail biokorozívneho napadnutia steny $\mathrm{v}$ podpivničenej časti je na obr. 2, pri diagnostike bol zrealizovaný aj vlhkostný prieskum a čiastočné chemické posúdenie.

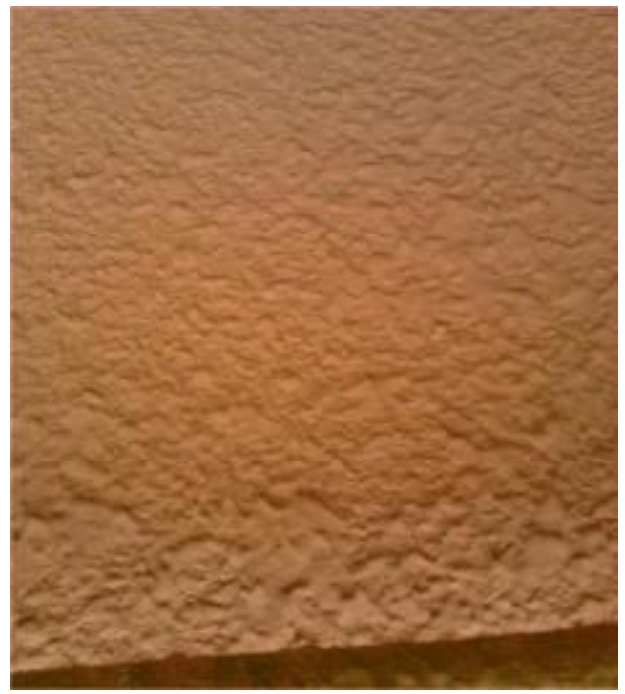

Obr. 1 Detail biokorozívneho napadnutia fasády (archív autora)

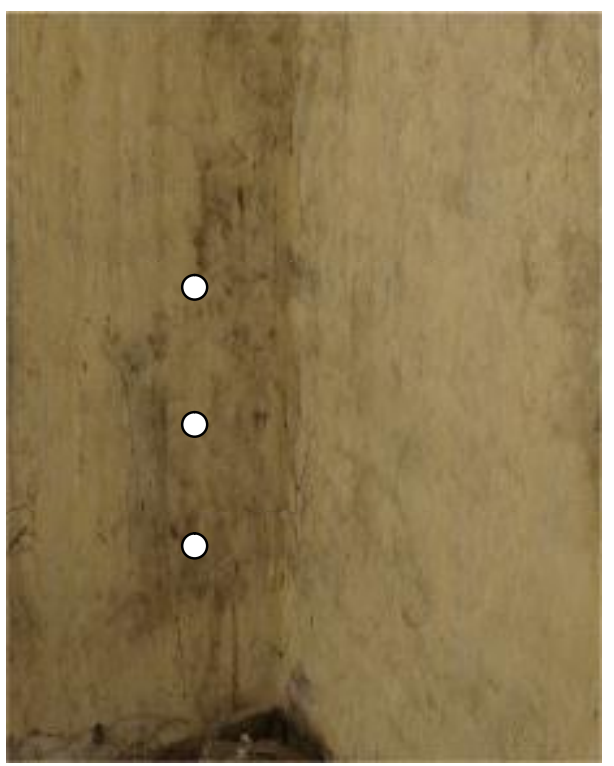

Obr. 2 Detail biokorozívneho napadnutia PP čast’ RD (archív autora) 


\subsection{Metodiky prieskumu}

Z praktických skúseností je možné vyslovit’ tvrdenie, že v podstate pri všetkých diagnostických prieskumoch biokorózie, ktoré sa týkajú silikátových materiálov sa vyžaduje individuálny prístup (Terpáková, 2008). Pre všeobecné skúšanie vlastností a chemického zloženia silikátových materiálov ako sú omietky, betón, malty apod. sa vychádza zo známych normových predpisov resp. pre prvky murovaných konštrukcií sa používajú odporučenia WTA smerníc na posúdenie napr. vlhkosti ale aj salinity - stanovenia koncentrácií dusičnanov, síranov a chloridov (WTA smernica 4-5-99).

Pri riešení biokorozívneho napadnutia stavebného prvku určitým biočinitel’om sa musia brat' do úvahy aj špecifiká týkajúce sa odberu a spracovania biologických materiálov a vzoriek (Wasserbauer, 2000). Takéto vzorky môžu byt' kontaminované aj napr. zdravotne škodlivými zložkami ako sú baktérie, mikromycéty a spóry plesní atd'.. Na základe výsledkov posúdenia sa následne realizuje analýza a hl'adanie možných technologických riešení sanácie (Antošová, 2013). Zvyčajne sa navrhujú viaceré varianty sanácie, z ktorých sa volí optimálne riešenie aj s prihliadnutím na ekonomické ukazovatele a to aj s prihliadnutím na nutné investície a prípadne aj s ohl'adom na dosiahnutie úspor (Antošová, 2015). Na tieto vyhodnotenia návrhov sa používajú aj multikriteriálne analýzy, v ktorých sa okrem cenových relácií zohl'adňuje aj časové hl'adisko realizácií, ochrana prostredia apod..

Prvý krok pri diagnostike biokorozívneho napadnutia je vizuálne posúdenie stavu daného miesta, na jeho základe je možné čiastočne zhodnotit' aj rozsah znečistenia miesta odberu. (Terpáková, 2012). Z publikovaných prác z oblasti posudzovania napr. biokorózie fasád po zateplení systémom ETICS vyplýva, že zvyčajným postupom pri diagnostike rozsahu znečistenia je určenie aj percentuálneho zastúpenia na stanovenej ploche. Ak je pokrytie povrchu mikroorganizmami napr. viac ako 50-62,5 \%, ide už o významné znečistenie (Antošová, 2015), vyžadujúce návrh sanácie.

Pre získanie detailnejších informácií o miere napadnutia a o druhoch mikroorganizmov je však už nutná aj mikrobiologická analýza, ktorá sa rieši na základe odobratých vzoriek z fasády. V literatúre sú popisované rôzne metodiky odberov (Wasserbauer, 2000), kedy sa používajú stery, obrusy $\mathrm{z}$ povrchu kontaminovanej konštrukcie, prípadne $\mathrm{v}$ uzavretých priestoroch $\mathrm{v}$ interiéri sa volia aj špeciálne sedimentačné metódy na posúdenie prítomností spór v ovzduší (Terpáková, 2012). Pre odber skúšobnej vzorky - kontaminovaného silikátového materiálu sa vždy stanoví výška resp. miesto odberov a to takým spôsobom, aby bola získaná reprezentačná vzorka $\mathrm{z}$ daného priestoru. Väčšinou ide o miesta s predpokladanou najväčšou kontamináciou stavebného prvku.

Na stery sa použijú sterilné tampóny, špachtle a iné pomôcky, ktoré sa tesne pred použitím ešte dezinfikujú napr. v 95\% etanole (Terpáková, 2012). Tampóny so sterom alebo zbrúsený silikát s mikroorganizmami sa urýchlene vložia do sterilnej vzorkovnice alebo sa zachytia na Petriho misku a následne sa dopravia do mikrobiologického laboratória. Vzorky sa v laboratóriu spracovávajú obvyklým spôsobom, t.j. za zachovania sterility, podrobujú sa kultivácii po stanovenú dobu (napr.7-14 dní, pri overenej pracovnej teplote atd'.), pozorujú pod mikroskopom. Mikromycety sa izolujú na jednotlivé druhy, následne sa pripravia mikroskopické preparáty, ktoré sa študujú vhodným optickým mikroskopom. Samotná identifikácia mikromycét sa realizuje podl'a signifikantných znakov. Na vyhodnotenie druhov sa používajú dostupné atlasy napr. (Fassatiová, 1976).

Súčast’ou mikrobiologického posúdenia napadnutého stavebného prvku a konštrukcie je aj vlhkostný prieskum, nakol'ko mikroorganizmy vyžadujú pre svoj rast vodu (Wasserbauer, 2000). Na stanovenie vlhkosti je možné zvolit' aj nedeštruktívny spôsob - priame stanovenie vlhkosti, konkrétne stanovenie vlhkosti v murive pivničných priestorov je dokumentované na obr. 3. Ak sa súčasne realizuje $\mathrm{v}$ danom mieste odber silikátovej vzorky pre mikrobiologické posúdenie, je nutné dodržat' aj sterilitu $\mathrm{v}$ mieste merania teploty resp. zabezpečit' očistu použitých meradiel. 
V rámci základných rozborov sa pre silikátové vzorky zvyčajne realizuje aj stanovenie salinity, zmien alkalickej reakcie, prípadne d’alšie stanovenia týkajúce sa chemického zloženia (vyjadrené ako prvková analýza).

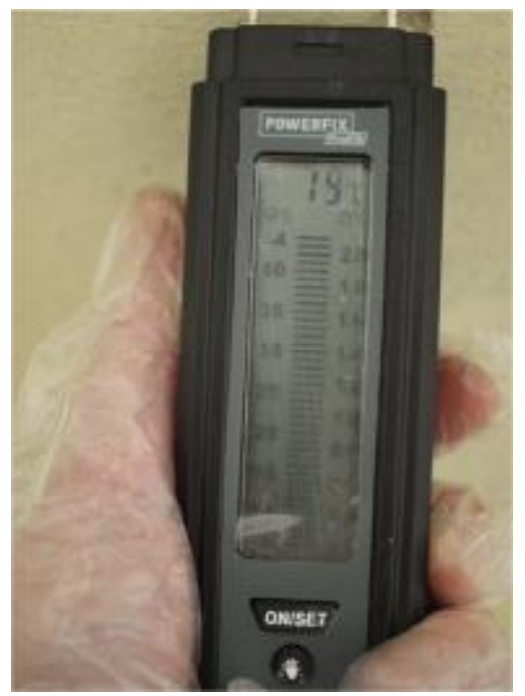

\section{Obr. 3 Meranie vlhkosti muriva odporovým vlhkomerom Powerfix Profi (archív autora)}

\section{Výsledky a diskusia}

Z posudzovaného rodinného domu boli po zvážení situácie a predbežnej obhliadke odobraté vzorky, jednak z fasády a tiež z pivničných priestorov. Už popísaným spôsobom boli z fasády odobraté stery, ktoré sa spracovali v mikrobiologickom laboratóriu, pričom bola identifikovaná prítomnost' nasledujúcich mikroorganizmov:

- Alternaria sp.,

- Aureobasidium sp.,

- Cladosporium sp.,

- Penicillium sp.

Detailné informácie - presná identifikácia všetkých druhov mikroorganizmov z pohladu bežného užívatel'a stavby nie sú až tak dôležité ako výber prostriedkov na ich likvidáciu a najmä úspešnost' sanácie napadnutých častí konštrukcie (v danom prípade častí fasády). V prípade experimentálneho overovania - aký druh prípravku je vhodný na likvidáciu mikroorganizmov sú v literatúre popisované prípadové štúdie, v ktorých autori na napadnuté povrchy nanášali vybrané chemické prípravky, nechali ich pôsobit' po určitú dobu (podl'a doporučeného postupu od výrobcu) a po ukončení ošetrovania a po vysušení povrchu sa vyhodnocovala účinnost' pôsobenia vzájomným porovnaním (Antošová, 2013), (Antošová, 2015).

$\mathrm{V}$ podstate sa $\mathrm{v}$ praxi na kontrolu účinnosti použitých fungicídnych prostriedkov využíva väššinou len uvedená vizuálna metóda, opakovaný mikrobiologický odber sa z prevádzkových dôvodov zvyčajne nevykonáva, a v podstate sa predpokladá, že pri dodržaní technologického predpisu od výrobcu budú mikroorganizmy odstránené.

V danom prípade sa na otestovanie účinnosti sanácie napadnutej časti fasády sa použili 2 rôzne prípravky A, B , naniesli sa na vytypované miesta a po ošetrení sa vykonalo opláchnutie a vysušenie ošetrovaného miesta. Výraznejšie účinky sa pozorovali pri prípravku A, takže na celú plochu sa napokon zvolil tento prostriedok. Získané výsledky boli čiastočne publikované (Terpakova, 2016). Ako d'alší postup nasledovalo:

- samostatné vizuálne posúdenie pomocou lupy ( zväčšenie 20x)

- fotodokumentácia stavu a detailné hodnotenie snímkov pri maximálnom rozlíšení

- opakovaný ster silikátovej vzorky sterilným skalpelom, 
- príprava výluhu v mikroskúmavke

- stanovenie $\mathrm{pH}$

- posúdenie prítomnosti chloridov ( prípravky boli na báze chlóru)

Meraním pH výluhu zo obrusu omietky z fasády sa potvrdilo, že použité prípravky nespôsobili radikálnu zmenu $\mathrm{pH}$, podobne sa nepreukázali zvýšené koncentrácie chloridov. Z pohl'adu užívatel’a bolo dôležité , že testované prípravky nespôsobili farebné zmeny fasády, ktoré boli očakávané, vzhl'adom na chemické zloženie aplikovaných prípravkov.

$\mathrm{Na}$ testovanie prítomnosti mikroorganizmov a spórov plesní sa v zahraničných zdrojoch uvádza aj používanie komerčne dostupných testerov, ktoré sa však využívajú najmä na kontrolu pracovného prostrediam napr. cielene na posúdenie prítomností určitých druhov mikroorganizmov v pobytových a zdravotníckych zariadeniach ako sú materské škôlky, byty apod. (napr. http://www.moldreport.com/mold_testing.html). Presnost' a spol'ahlivost' stanovení takýmito testermi resp. doba na získanie výsledku je individuálna.

Pre posúdenie degradácie muriva v pivničných priestoroch RD sa mechanicky odobrali 3 vzorky omietok do cca $10 \mathrm{~mm}$ (vrátane povrchových solí) z výšky $0.5 \mathrm{~m}, 1.0 \mathrm{~m}$ a $1.5 \mathrm{~m}$ od úrovne podlahy, v rohovej časti pivnice (východná a južne orientovaná stena), kde sa pozorovala prítomnost' plesní (Obr.2). Súčasne sa premerala vlhkost' odporovým vlhkomerom Powerfix Profi , pričom orientačným meraním bola stanovená vlhkost' muriva cez rozsah merača $(\mathrm{w}>2 \%)$. Z odberov sa neskôr pri laboratórnom stanovení hmotnostnej vlhkosti stanovili priemerné hmotnostné vlhkosti v rozsahu až $\mathrm{w}_{\mathrm{hm}} 10 \approx 12 \%$, čo v zmysle hodnotení podl'a WTA smerníc (WTA smernice: 4-5-99) už znamená vel'mi vysokú vlhkost'.

Vzorky po stanovení hmotnostnej vlhkosti sa následne použili na posúdenie salinity a alkalickej reakcie. Miesta odberov sú naznačené na obr. 2. Ďalšie odbery t. č. síce neboli vykonané, ale v priestore PP posudzovaného RD sa plánuje inštalácia nového plynového kotla na vykurovanie a s tým budú spojené rozsiahlejšie sanačné zásahy aj do obvodového muriva a stropnej časti PP, vrátane rekonštrukcie podlahovej časti, čím sa zároveň zrealizuje aj sanácia vlhkosti. Na obnažených častiach murív sa zároveň bude môct' vykonat' aj híbkový prieskum salinity.

V rámci posúdenia degradácie sa odobraté vzorky detailnejšie pozorovali aj pod mikroskopom Bresser, detaily z odberu 2 (z výšky 1.0m). sú dokumentované na obr.4. Na jednotlivých zrnách omietky sú viditel'né aj prítomnosti mikroorganizmov s typickým zafarbením. Vzhl’adom na uvedenú skutočnost', boli d'alšie stanovenia vykonané za zvýšených hygienických podmienok.

Výsledky posúdenia salinity a alkalickej reakcie sú zosumarizované v tab.1. Z porovnania výsledkov vyplýva, že vyššie koncentrácie solí boli stanovené vo výške $1.5 \mathrm{~m}$, čo súvisí s kapilárnym vzlínaním.

V zmysle kritérií, ktoré sú v súčasnosti používané na hodnotenie salinitity murív (WTA smernice) vyplýva, že v daných odberných miestach je stredná až vysoká zát’až chloridmi, resp. stredná zát'až dusičnanmi. Uvedená skutočnost' môže súvisiet' so situovaním RD a čiastočne so spôsobom využívania susednej parcely na pestovanie zeleniny a drobného ovocia.

Presné gravimetrické stanovenie vlhkosti zdôraznilo potrebu sanácie vlhkosti z južnej strany $\mathrm{RD}$, ktorá pri predchádzajúcich rekonštrukčných zásahoch nebola riešená. Na prítomnost' solí v omietkách je určite naviazaná aj prítomnost' mikroorganizmov, čo je potrebné riešit' použitím vhodného fungicídneho prostriedku na ich odstránenie. V budúcnosti pri plánovanom rekonštrukčnom zásahu sa zároveň očakáva zlepšenie vlhkostno-tepelných podmienok v priestoroch PP, takže je vysoká pravdepodobnost', že prítomnost' plesní nebude pozorovaná, ked’že sa odstránia životné podmienky na ich rast. 


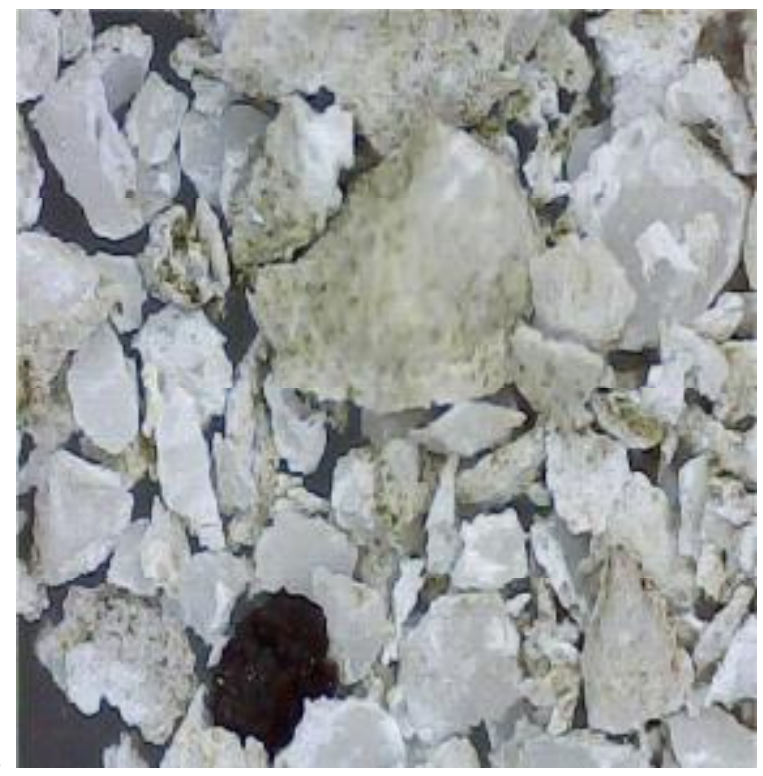

Obr.4 Detail odberu omietky, PP čast' RD (výška 1.0m) Mikroskop Beresser, zväščenie 20x (archív autora)

\begin{tabular}{|c|c|c|c|c|c|c|}
\hline Parameter & \multicolumn{2}{|c|}{ Odber č. 1} & \multicolumn{2}{|c|}{ Odber č. 2} & \multicolumn{2}{|c|}{ Odber č. 3} \\
\hline & soli & omietka & soli & omietka & soli & omietka \\
\hline $\begin{array}{l}\text { Alkalita } \\
\text { pH vzoriek }\end{array}$ & 8,35 & 9,46 & $\mathbf{7 , 5 8}$ & 9,30 & $\mathbf{7 , 8 0}$ & 9,12 \\
\hline $\begin{array}{l}\mathrm{C} \text { chloridov } \\
\text { [\%] }\end{array}$ & 0.15 & $\mathbf{0 , 3 0}$ & $\mathbf{0 , 0 2}$ & $\mathbf{0 , 3 2}$ & 0,15 & 0,55 \\
\hline salinita & & $\begin{array}{c}\text { Stredná } \\
\text { zátaž }\end{array}$ & & $\begin{array}{c}\text { Stredná } \\
\text { zátaž }\end{array}$ & & $\begin{array}{l}\text { Vysoká } \\
\text { zátazaz }\end{array}$ \\
\hline $\begin{array}{l}\text { C } \\
\text { dusičnanov } \\
{[\%]}\end{array}$ & 0.04 & 0,12 & $\mathbf{0 , 0 3}$ & 0,15 & 0,04 & 0,26 \\
\hline salinita & & $\begin{array}{c}\text { Stredná } \\
\text { zátaž }\end{array}$ & & $\begin{array}{l}\text { Stredná } \\
\text { zátaž }\end{array}$ & & $\begin{array}{c}\text { Stredná } \\
\text { zátaž }\end{array}$ \\
\hline $\begin{array}{l}\text { Hmotnostná } \\
\text { vlhkost' [\%] }\end{array}$ & 9,8 & 10,2 & $\mathbf{7 , 9}$ & 10,63 & 9,24 & 11,15 \\
\hline
\end{tabular}

Tab. 1 Výsledky posúdenia salinity a vlhkosti odobratých vzoriek

\section{ZÁVER}

Diagnostické posúdenia napadnutých častí konštrukcií mikroorganizmami majú určite zmysel, nakol'ko získané informácie môžu byt' využité ako rozhodovací prvok pri výbere sanačných postupov na jednej strane a zároveň ako kontrolný prvok pri overovaní účinnosti likvidácie mikromycét. Dominantným záujmom ako realizátora sanácie ako aj vlastníka resp. užívatel’a stavby, je naplnenie základných požiadaviek na stavbu, ktorými sú aj trvanlivost' a hygienická nezávadnost' stavebného diela.

Pod'akovanie: príspevok je spracovaný ako súčast’ riešenia projektu VEGA 2/0145/15. 


\section{Použitá literatúra}

[1] Antošová N., Impact of biocorrosion on the durability of ETICS and empirical findings about the periodicity of maintenance, Slovak Journal of Civil Engineering 2013,vol. 21, issue 2, pp. 21-28, DOI: 10.2478/sjce-2013-0009

[2] Antošová, N.: Metodika výberu technológie pre elimináciu mikroorganizmov na ETICS Czech Journal of Civil Engineering 2015,1, s. 6-14, ISSN 2336-7148

[3] Fassatiová, Olga: Plísně a vláknité houby v technické mikrobiologii. SNTL, Praha, 1979: 240 p., Typové číslo L18-B2-IV-32/82126

[4] On line: http://www.ea-etics.eu/views/etics/about-etics.html

[5] STN 73 0540-2:2012 Tepelná ochrana budov: Tepelnotechnické vlastnosti stavebných konštrukcií a budov. Čast' 2: Funkčné požiadavky, platné od 1.1.2013

[6] Terpáková, E.: The study of building biocorrosion.In: Chemické Listy. Vol. 102 (S), no. Symposia (2008), p.919-920. ISSN 0009-2770

[7] Terpáková, E.- Eštoková, A.: Analytical support in solving bio-corrosion of fasade systems ETICS, SGEM 2016, Section Green Buildings Technologies and Materials, pp.1-6 (in press)

[8] Terpáková E., Čonková E., Švajlenka J. The importance of multidisciplinary analytical approach to solving problems of biocorrosion in civil building ESAS 2012: European Symposium on Atomic Spectrometry: 20th Slovak-Czech Spectroscopic Conference : Book of Abstracts: October 7 - 12. 2012, Tatranská Lomnica, Slovakia. Bratislava : Comenius University, 2012, pp. 197, ISBN 978-80-223-3292-7

[9] Wasserbauer R., Biologické znehodnocení staveb (Biological damaged of buildings). ABF, a.s. Prague, 2000; pp. 280, ISBN 80-86165-30-2

[10] WTA smernice 4-5-99: Posouzení zdiva - diagnostika zdiva (novelizovaná 4-5-97).

[11] http://www.moldreport.com/mold_testing.html 